\title{
Gender Differences in Voluntary Turnover: Still a Paradox?
}

\author{
Tae Heon Lee \\ Correspondence: Tae Heon Lee, School of Business, North Carolina Central University, Durham, NC, USA. Tel: \\ 1-919-530-7385. E-mail: taeheon@nccu.edu
}

Received: July 28, 2012

Accepted: August 14, 2012

Online Published: September 3, 2012

doi:10.5539/ibr.v5n10p19

URL: http://dx.doi.org/10.5539/ibr.v5n10p19

\begin{abstract}
This study addresses three important questions that may have substantial implications for gender inequalities in the labor market. First, are women more content with their jobs than men? Second, are women more prone to voluntary turnover than men? Third, given different reasons for turnover, does job satisfaction have differential effects on different turnover paths? Using a large national sample, the framework of the unfolding model of turnover, survival analyses, and other analytical methods, this study found no supporting evidence for the first two questions, but found new evidence supportive of the third question. Unlike many previous studies that used a single turnover category aggregating all kinds of voluntary turnover, this study separated voluntary leavers into several different types of turnover based on specific reasons for turnover, which allowed this study to explore the above questions from new perspectives. The propositions of the unfolding model provide promising avenues for future research to follow. The results of this study also suggest an important practical implication that organizations need to implement retention policies and practices tailored to different reasons of turnover, as opposed to generic ones.
\end{abstract}

Keywords: gender, voluntary turnover, job satisfaction, unfolding model, survival analyses

\section{Introduction}

Given the persisting gender inequalities in the labor market and the workplace, it may sound paradoxical that women are more satisfied than men with their jobs, yet more prone to voluntary turnover. As Phelan (1994) suggested, the understanding of this behavioral paradox may have extremely important implications for uncovering the underlying causes of gender inequalities in salary and other job-related outcomes. Yet, earlier studies found conflicting results regarding the existence of these behavioral phenomena (Blau \& Kahn, 1981; Clark, 1997; Crosby, 1982; Light \& Ureta, 1992; Lyness \& Judiesch, 2001; Mueller \& Wallace, 1996; Phelan, 1994; Royalty, 1998; Suosa-Poza \& Suosa-Poza, 2007). Though some researchers suggested theoretical explanations for these seemingly irrational behavioral patterns of women in the labor market, a universal consensus regarding the existence of these phenomena has yet to be reached. In order to be able to suggest any theoretical explanations and practical remedies for these issues, more research effort needs to be directed to fact-finding. That is, the existence of this paradox needs to be resolved first.

The present study addresses three important sub-questions involved in the above discussion that may have serious implications for the observed gender gaps in the labor market outcomes. First, a paradoxical observation, called the "paradox of the contented female worker," was made in some countries including the United States (Clark, 1997; Crosby, 1982; Mueller \& Wallace, 1996; Phelan, 1994; Suosa-Poza \& Suosa-Poza, 2007). If women tend to be more satisfied with their jobs than men despite lower wages/salaries and other worse work conditions, it could be one of the root causes for the gender inequalities in the labor market. Second, earlier studies found gender differences in employee turnover propensities (Blau \& Kahn, 1981; Griffeth, Hom, \& Gaertner, 2000; Lee, Gerhart, Weller, \& Trevor, 2008; Light \& Ureta, 1992; Lyness \& Judiesch, 2001; Royalty, 1998). As some studies suggested, the higher average turnover propensities of women may also have a negative effect on the position of women in the labor market. Third, job satisfaction is an established predictor of turnover. Given the gender differences in job satisfaction and job mobility, another interesting question implied by the above two questions is whether the effect of job satisfaction on turnover is gender-specific across different reasons for turnover.

Using a large national sample (National Longitudinal Survey of Youth 79: NLSY79), this study addresses the aforementioned issues to shed further light on the paradox. The objective of this study is threefold. First, this study empirically tests gender differences in job satisfaction. Second, unlike most previous studies, this study 
separates different reasons for turnover and estimates the gender differences in turnover propensities across different reasons for turnover. Third, this study estimates and compares the differential effects of job satisfaction on turnover by gender across different reasons for turnover.

\section{Literature Review}

\subsection{Gender Difference in Job Satisfaction}

Most voluntary turnover models conceptualize job satisfaction as a key job-related attitude that initiates the voluntary turnover process. Since March and Simon's (1958) influential work on turnover, the perceived desirability of quitting has been equated with the level of job satisfaction (Jackofsky \& Peters, 1983; Lee \& Mitchell, 1994). Also, previous empirical studies and meta-analyses reported job satisfaction as a valid predictor of future job quits (Clark, 2001; Griffeth \& Hom, 1995; Griffeth, Hom, \& Gaertner, 2000; Mobley, Griffeth, Hand, \& Meglino, 1979; Tett \& Meyer, 1993).

Since Crosby (1982) coined the phrase, "the paradox of the contented female worker," women's higher job satisfaction observed in some countries has drawn research attention because of its potential link to gender differences in job-related outcomes such as wages, promotion, training, and so on. Mueller and Wallace (1996) questioned "why are women consistently satisfied with less?" (p. 338). A number of studies have investigated this topic, and found mixed results. For example, Phelan (1994), using a sample of professionals and managers, tested five socio-psychological hypotheses to explain gender difference in organizational satisfaction, and found no significant gender difference in organizational satisfaction despite differing working conditions, evidence which supports the observed paradox. Clark (1997) used panel data, and found that job satisfaction was significantly higher for women even after controlling for a number of variables, and that gender difference in job satisfaction was affected by age, education level, and occupation. Sousa-Poza and Sousa-Poza (2000) in their analysis of 21 countries found that after controlling for several factors, gender differences in job satisfaction were significant only in the United States, Great Britain, and Switzerland. In contrast, Mueller and Wallace (1996) in their study of lawyers found no significant gender differences in global job satisfaction after controlling for other variables, and suggested that the claims of a paradox may have been due to model misspecifications of job satisfaction in previous studies. Sloane and Williams (2000) argued that the observed higher level of women's job satisfaction may be due to the fact that women tend to self-select themselves into certain kinds of jobs to maximize their job satisfaction. Similarly, Sousa-Poza and Sousa-Poza (2007) concluded that the observed female employees' higher job satisfaction can be explained by the fact that more dissatisfied women employees decide to withdraw from the labor force, and thus refuted the gender differential paradox. In sum, it appears that differing results in previous studies can be at least partially attributed to the use of different samples, control variables, model specifications, and research designs.

\subsection{Gender Difference in Turnover Propensities}

Another interesting, yet very important question in relation to gender inequalities in the labor market, is whether women are more likely to leave their jobs. Sousa-Poza and Sousa-Poza (2007) noted that "this result has far-reaching consequences because differing job-mobility inclinations between genders affect probability of being promoted, accumulation of human capital, and wages" (p. 896). In the same vein, Lyness and Judiesch (2001) cited the suggestion made by Light and Ureta (1992) that "employers may equate 'female' with 'quitter' because women have higher average turnover rates than men" (p. 156).

As with gender differences in job satisfaction, there were mixed findings in previous studies. For instance, in their study using the National Longitudinal Survey of young men and women, Blau and Kahn (1981) reported that overall turnover rates were higher for women than men, but when personal and job characteristics were controlled for, no significant gender differences in turnover rates were found. Using the National Longitudinal Survey of Young men and women, and the National Longitudinal Survey of Youth, Donohue (1988) found that women's higher quit rates were contingent on tenure, and suggested family-related reasons like pregnancy as an explanation for the increasing turnover hazard early in the tenure of their first job. Light and Ureta (1992), using the National Longitudinal Survey of young men and women, found that women were less likely to quit their jobs after controlling for unobserved heterogeneity. Lynch (1992) used the National Longitudinal Survey of Youth, and found no significant gender difference after controlling for a set of variables. Using the data from the same survey, Royalty (1998) found that the higher average turnover rate of women was largely due to the high turnover rate of less educated women (e.g., high school or less). Using a private company's personnel records, Sicherman (1996) found that after controlling for personal and job characteristics, men and women showed similar turnover patterns. But, when different reasons for turnover were considered, there were significant differences in turnover behaviors between men and women. For example, women were more likely to leave their 
jobs for personal or family-related reasons. Other studies (e.g., Lee et al., 2008; Sicherman, 1996; Theodossiou, 2002) also reported similar findings. Probably reflecting these mixed results, some recent studies including meta-analyses found that gender is a weak predictor of turnover (Allen, Bryant, \& Vandaman, 2010; Bauer, Bonder, Erdogan, Truxillo, \& Tucker, 2007; Griffeth, Hom, \& Gaetner, 2000).

Despite a variety of mixed empirical findings, a few common findings emerge from previous studies. First, overall turnover rates tend to be higher for women, especially at the early stage of tenure. Second, when personal and job characteristics are included in the analysis, the differences in turnover propensities between men and women tend to decrease or disappear. Third, overall turnover rates do not reveal substantial differences in turnover patterns between men and women across different reasons for turnover.

\subsection{Differential Effects of Job Satisfaction on Turnover by Gender and Different Turnover Reasons}

In their study of the aforementioned paradox, Sousa-Poza and Sousa-Poza (2007) raised another important question. That is, given that turnover is influenced by job satisfaction, some studies suggest that there are gender gaps in job satisfaction and turnover propensities. Then, would there be gender-specific differences in the extent to which job satisfaction influences turnover? The answer to this question may shed further light on the debate about women's weaker job attachment and gender inequalities in the labor market. In addition, as mentioned in the previous section, some studies found that there are substantial and systematic gender differences in turnover behaviors and propensities depending on specific reasons for turnover (Hochwater, Ferris, Canty, Frink, Ferrewe, \& Berkson, 2001; Lee et al., 2008; Sicherman, 1996; Lee \& Mitchell, 1994; Theodossiou, 2002). Yet, previous literature rarely addressed the interrelationships between job satisfaction, gender, and different turnover reasons.

In the turnover literature, there has been an increasing recognition that the use of a single turnover category aggregating all different reasons of turnover may have contributed to the lack of the predictive validity of turnover models (Lee \& Mitchell, 1994; Lee, Mitchell, Wise, \& Fireman, 1996; Mitchell, Holtom, Lee, \& Graske, 2001). Citing Royalty (1998), Sousa-Poza and Sousa-Poza (2007) suggested that "an aggregation of job-to-job and job-to-non-employment turnover obscures important patterns" (p. 900). In a similar vein, Sicherman (1996) concluded his study with the statement that "as long as women differ from men in reasons for quitting, analyses that focus on simply the overall quit rate will be incomplete and potentially misleading" (p. 502). In response, new conceptual approaches to turnover have been proposed. In particular, the unfolding model of turnover (e.g., Lee \& Mitchell, 1994) suggests a promising route to follow in answering the above questions. Several propositions of the unfolding model bear very important implications for this study. First, unlike most traditional conceptual models of turnover, the unfolding model explicitly recognizes the existence of multiple possible turnover paths. That is, different reasons initiate different paths of turnover. Second, the unfolding model suggests that job satisfaction may have differential effects on turnover in different turnover paths. For instance, in turnover cases where female employees have to leave their jobs for family-related reasons, or employees leave their current jobs to take an unsolicited job offer, these employees may not necessarily be dissatisfied with their current jobs. These kinds of turnover were not fully conceptualized in traditional turnover models in which job dissatisfaction is a key initiator of turnover. A recent study based on the framework of the unfolding model found that the effect of job satisfaction on turnover was much smaller for family-related turnover than for other types of turnover (Lee et al., 2008). Along with the consistent finding that a much higher number of women than men leave their jobs for personal or family-related reasons, these results suggest that different reasons for turnover should be considered to resolve the debate about gender differences in job satisfaction and turnover propensities.

\section{Method}

\subsection{Data}

The present study uses the data from the National Longitudinal Survey of Youth, 1979 Cohort (NLSY79). The NLSY79 is an annual survey (biannual after 1994) of a nationally representative sample of young men and women, and the first survey was conducted in 1979. The present study uses the data from the 1996 to 2000 surveys which contain specific information on the reasons for voluntary turnover necessary to make a distinction between different types of voluntary leavers as defined in the present study. The sample used in the current study consists of the 1996 interviewees who provided information on their current or most recent job (also called a CPS job). The age of the sample ranged from 31 to 38 as of the 1996 interview date. A longitudinal employment history for the 1996 CPS job up to the date of the 2000 survey was created for each subject, which contains information on tenure, job satisfaction, wages, working hours, demographics, etc. After excluding respondents who were self-employed, working in a family business, or actively serving in the armed forces, and respondents 
with missing information, the final sample was reduced to 6,199 . The total number of observations used in the analyses is larger than the original sample size because each subject has multiple observations over the study period.

\subsection{Measures}

\subsubsection{Voluntary Turnover}

Five different categories of turnover were identified using the information on reasons for leaving the 1996 CPS job (involuntary turnover, voluntary turnover to look for a job, voluntary turnover to take another job, voluntary turnover for pregnancy or other family reasons, and voluntary turnover for other reasons). This study focuses on voluntary turnover to look for a job, voluntary turnover to take another job, and voluntary turnover for pregnancy or other family reasons, which are labeled Type 1, Type 2, and Type 3, respectively.

\subsubsection{Job Satisfaction}

Using a survey question measuring global job satisfaction, "How do/did you feel about your job?" a four-point scale was used: "dislike it very much" (1), "dislike it somewhat" (2), "like it fairly well" (3), "like it very much" (4).

\subsubsection{Control Variables and Tenure}

Tenure is total tenure in weeks at each reported job. This variable is used as a duration variable (analysis time until turnover) in the survival analyses. Relative pay represents an individual's pay level relative to the average pay level individuals with similar characteristics can expect to earn in the individual's three-digit occupation category, and was created by using the information on hourly pay in the NLSY and the Current Population Survey. Work hour is the usual weekly work hours at the job. Total number of jobs represents the total accumulated number of jobs a respondent has held during his/her working career. Education level is the highest grade completed. Sex was coded 1 for male, 2 for female. Race was coded 0 for non-white, 1 for white. Marital status was coded 0 for non-married (i.e., never married, divorced, separated, etc.), 1 for currently married. Age is a continuous variable as of each interview date.

\subsection{Analytical Methods}

This study uses the survival analysis technique to estimate gender differentials in turnover hazards, and differential effects of job satisfaction on turnover. The advantages of survival analysis over other analytical methods for turnover research are well documented in the literature (e.g., Morita, Lee, \& Mowday, 1989; Somers \& Birnbaum, 1999). A key advantage of survival analysis is that it analyzes time until the occurrence of an event of interest (e.g., time until turnover). Thus, both the occurrence and timing of turnover can be simultaneously analyzed. More specifically, this study uses a semi-parametric proportional hazards model, known as a Cox regression model (Cox, 1972). The hazard function of the model is given with

$$
h(t, \boldsymbol{x})=h_{0}(t) \exp (\beta \boldsymbol{x})
$$

where $h_{0}(t)$ is the baseline hazard, $\boldsymbol{x}$ is the vector of covariates, and $\beta$ is the vector of regression coefficients. The base line hazard can be interpreted as the same base hazard of turnover everyone faces. Thus, individuals' hazards of turnover are determined by individual differences in the values of the covariates. This study also uses ordered probit models to estimate gender difference in job satisfaction and the effects of other control variables on job satisfaction.

\section{Results}

Table 1 presents the means, standard deviations, and correlations among the variables. Table 2 reports the results of the ordered probit regressions on job satisfaction. In the second column, the coefficient of sex is positive and significant, which means that females tend to be more satisfied with their jobs. But, the third column shows that when other variables were controlled for, the sex coefficient became insignificant, indicating no gender difference in job satisfaction. Other factors positively related to job satisfaction were age, marriage, educational level, and relative pay level. Tables 3 to 6 report the results of the Cox proportional hazards regressions across different turnover reasons by gender. Table 3 reports the results for all types of voluntary leavers which included Types 1 to 3 and voluntary leavers for unspecified reasons. Several results are worth noting. First, when both men and women were included in the analysis (the second column), the positive sex coefficient indicates that women are more prone to voluntary quitting. This result seems to support the aforementioned paradox. But, as will be shown later, separate analyses for different turnover reasons show different turnover patterns between men and women. Second, older employees and employees with higher levels of job satisfaction, relative pay, and education were less likely to leave their jobs. Third, when analyzed separately, married women were more likely 
to quit their jobs, which probably reflects the well established fact that women are more likely than men to leave their jobs due to family reasons and domestic commitments (Lyness \& Judiesch, 2001; Theodossiou, 2002).

Table 1. Means, Standard Deviations, and Correlations

\begin{tabular}{|c|c|c|c|c|c|c|c|c|c|c|}
\hline & Mean & S.D. & 1 & 2 & 3 & 4 & 5 & 6 & 7 & 8 \\
\hline 1. Job satisfaction & 3.29 & .74 & & & & & & & & \\
\hline 2. Relative pay & 1.07 & .64 & .08 & & & & & & & \\
\hline 3. Total jobs & 9.70 & 5.46 & -.05 & -.07 & & & & & & \\
\hline 4. Work hours & 40.68 & 10.72 & .01 & .35 & .01 & & & & & \\
\hline 5. Sex & 1.49 & .49 & .01 & -.01 & -.08 & -.30 & & & & \\
\hline 6. Age & 36.15 & 2.79 & .02 & .03 & -.15 & .03 & .01 & & & \\
\hline 7. Race & .66 & .47 & .04 & .05 & .05 & .02 & -.02 & .02 & & \\
\hline 8. Married & .57 & .49 & .07 & .05 & -.10 & -.00 & -.05 & .07 & .23 & \\
\hline 9. Education & 13.23 & 2.38 & .06 & .04 & .06 & .02 & .06 & .04 & .10 & .10 \\
\hline
\end{tabular}

Note: $n=14,362$; Correlation coefficients significant at the $5 \%$ level or better in bold.

Table 2. Determinants of job satisfaction

\begin{tabular}{lllll}
\hline & \multicolumn{3}{c}{ Ordered Probit: Job satisfaction } \\
\cline { 2 - 5 } & \multicolumn{1}{c}{$\boldsymbol{b}$} & s.e. & $\boldsymbol{b}$ & s.e. \\
\hline Sex & $.08^{* *}$ & .03 & .06 & .03 \\
Age & & & $.02 * *$ & .00 \\
Race & & -.01 & .03 \\
Married & & $.10^{* *}$ & .03 \\
Education & & $.02^{* *}$ & .01 \\
Relative pay & & $.18^{* *}$ & .03 \\
Total jobs & & $-.01^{* *}$ & .00 \\
Work hours & & -.00 & .00 \\
Log likelihood & & & 6820 & \\
Log likelihood-ratio $\left(\chi^{2}\right)$ test & -6888 & & $143.92^{* *}$ & \\
\hline
\end{tabular}

Note: $\boldsymbol{b}$ : Coefficients. s.e.: Standard errors. ${ }^{* *}$ Significant at the $1 \%$ level.

Table 3. Cox proportional hazards regression: All voluntary turnover

\begin{tabular}{|c|c|c|c|c|c|c|}
\hline & \multicolumn{2}{|c|}{ All } & \multicolumn{2}{|c|}{ Male } & \multicolumn{2}{|c|}{ Female } \\
\hline & $b$ & s.e. & $b$ & s.e. & $b$ & s.e. \\
\hline Job satisfaction & $-.48 * *$ & .02 & $-.56 * *$ & .03 & $-.42 * *$ & .03 \\
\hline Relative pay & $-.46^{* *}$ & .05 & $-.42 * *$ & .07 & $-.45 * *$ & .08 \\
\hline Total jobs & $.05 * *$ & .00 & $.05 * *$ & .01 & $.05 * *$ & .01 \\
\hline Work hours & $.01 * *$ & .00 & $.01^{* *}$ & .00 & .00 & .00 \\
\hline Sex & $.26^{* *}$ & .04 & & & & \\
\hline Age & $-.16 * *$ & .01 & $-.15 * *$ & .01 & $-.16 * *$ & .01 \\
\hline Race & -.04 & .05 & -.11 & .07 & -.03 & .06 \\
\hline Married & .06 & .04 & -.09 & .06 & $.15^{*}$ & .06 \\
\hline Education & $-.02 *$ & .01 & .00 & .01 & $-.04 * *$ & .01 \\
\hline Log likelihood & -15738 & & -6559 & & -7565 & \\
\hline Log likelihood-ratio $\left(\chi^{2}\right)$ test & $1009.59 * *$ & & $539.62 * *$ & & $493.57 * *$ & \\
\hline
\end{tabular}

Note: $\mathrm{n}=14,362$ spells. $\boldsymbol{b}$ : Coefficients. s.e.: Standard errors. **, * Significant at the $1 \%$ and $5 \%$ level, respectively.

Figure 1 provides additional information about the turnover patterns of men and women. First, overall turnover hazards are higher for women than men. Second, turnover hazards of both genders increase at the early tenure, continually decrease over tenure, and eventually tend to converge. Table 4 reports the results for Type 1 turnover (quit to look for a job) which is equivalent to job-to-unemployment turnover in the economics and sociology literature. First, for both genders job satisfaction, relative pay level, age, and total number of jobs were the significant predictors of turnover. Second, job satisfaction and relative pay level, in particular, had a very strong effect on this type of turnover, and the effect of job satisfaction on turnover was stronger for women than men. 
Figure 2 shows that in the first few years of tenure, turnover hazards were higher for men than women, but at the later stage of tenure, there was no systematic gender difference in turnover hazards.

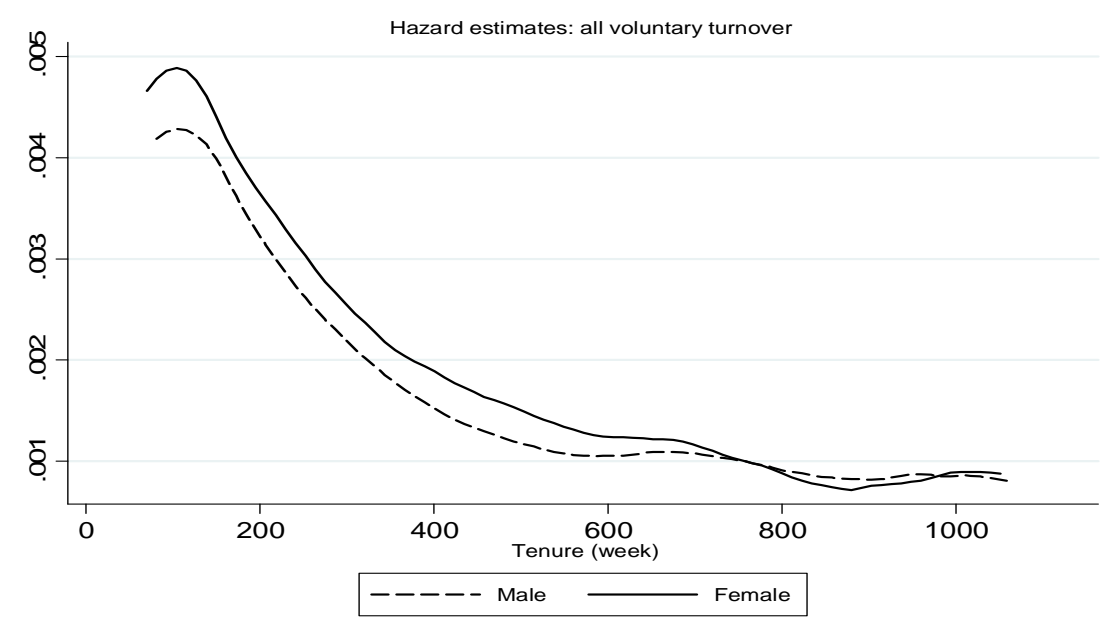

Figure 1. Turnover hazards for all voluntary turnover

Table 4. Cox proportional hazards regression: Type 1 (Quit to look for a job)

\begin{tabular}{|c|c|c|c|c|c|c|}
\hline & \multicolumn{2}{|c|}{ All } & \multicolumn{2}{|c|}{ Male } & \multicolumn{2}{|c|}{ Female } \\
\hline & $b$ & s.e. & $b$ & s.e. & $b$ & s.e. \\
\hline Job satisfaction & $-.81 * *$ & .07 & $-.77 * *$ & .10 & $-.91 * *$ & .11 \\
\hline Relative pay & $-1.35 * *$ & .23 & $-1.47 * *$ & .31 & $-1.08 * *$ & .35 \\
\hline Total jobs & $.05 * *$ & .01 & $.06 * *$ & .02 & $.05 * *$ & .02 \\
\hline Work hours & $.03^{* *}$ & .01 & $.03^{* *}$ & .01 & .02 & .01 \\
\hline Sex & .12 & .16 & & & & \\
\hline Age & $-.17 * *$ & .03 & $-.14 * *$ & .04 & $-.21 * *$ & .05 \\
\hline Race & .02 & .16 & -.14 & .21 & .15 & .24 \\
\hline Married & $-.44 * *$ & .15 & $-.64 * *$ & .22 & -.24 & .23 \\
\hline Education & $-.10 * *$ & .03 & -.02 & .04 & $-.19 * *$ & .05 \\
\hline Log likelihood & -1220 & & -596 & & -487 & \\
\hline $\log$ likelihood-ratio $\left(\chi^{2}\right)$ test & $222.65 * *$ & & $123.14 * *$ & & $114.82 * *$ & \\
\hline
\end{tabular}

Note: $\mathrm{n}=14,362$ spells, $\boldsymbol{b}$ : Coefficients. s.e.: Standard errors. ** Significant at the $1 \%$ level.

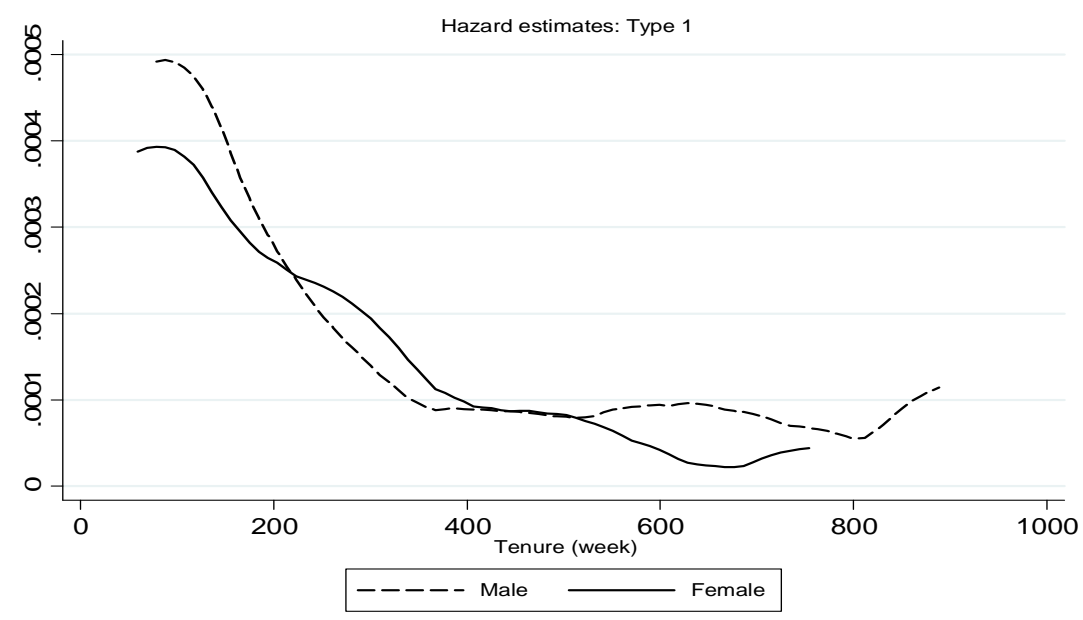

Figure 2. Turnover hazards for Type 1 turnover: quit to look for a job 
Table 5 reports the results for Type 2 turnover (quit to take another job). One main difference between Type 1 and Type 2 is that Type 2 leavers left their jobs with an alternative job in hand. As in Type 1, job satisfaction, relative pay level, age, and total number of jobs influenced turnover hazards for both genders, and in particular, the effects of job satisfaction and relative pay level were the strongest. Also, married men and women were more likely to quit their jobs to take another job. A possible explanation is that married people are risk averse and more likely than the unmarried to secure another job before quitting. The positive coefficient of work hours for women indicates that women working long hours were more likely to quit their jobs to take a less demanding job. Figure 3 shows that Type 2 turnover hazards were consistently higher for men than women except for the late stage of tenure.

Table 5. Cox proportional hazards regression: Type 2 (Quit to take another job)

\begin{tabular}{|c|c|c|c|c|c|c|}
\hline & \multicolumn{2}{|c|}{ All } & \multicolumn{2}{|c|}{ Male } & \multicolumn{2}{|c|}{ Female } \\
\hline & $b$ & s.e. & $b$ & s.e. & $b$ & s.e. \\
\hline Job satisfaction & $-.65 * *$ & .04 & $-.75 * *$ & .05 & $-.50 * *$ & .06 \\
\hline Relative pay & $-.43 * *$ & .09 & $-.34 * *$ & .11 & $-.62 * *$ & .16 \\
\hline Total jobs & $.05 * *$ & .01 & $.05 * *$ & .01 & $.06 * *$ & .01 \\
\hline Work hours & .01 & .00 & .00 & .01 & $.02 *$ & .01 \\
\hline Sex & $-.21 * *$ & .08 & & & & \\
\hline Age & $-.15 * *$ & .02 & $-.16^{* *}$ & .02 & $-.15 * *$ & .02 \\
\hline Race & $.18^{*}$ & .09 & .22 & .11 & .10 & .13 \\
\hline Married & $.27 * *$ & .08 & $.27 *$ & .10 & $.30^{*}$ & .12 \\
\hline Education & $.05 * *$ & .01 & $.09 * *$ & .02 & -.01 & .03 \\
\hline Log likelihood & -4888 & & -2521 & & -1858 & \\
\hline Log likelihood-ratio $\left(\chi^{2}\right)$ test & $487.91 * *$ & & $322.40^{* *}$ & & $167.98^{* *}$ & \\
\hline
\end{tabular}

Note: $\mathrm{n}=14,362$ spells. $\boldsymbol{b}$ : Coefficients. s.e.: Standard errors. **, * Significant at the 1\% and 5\% level, respectively.

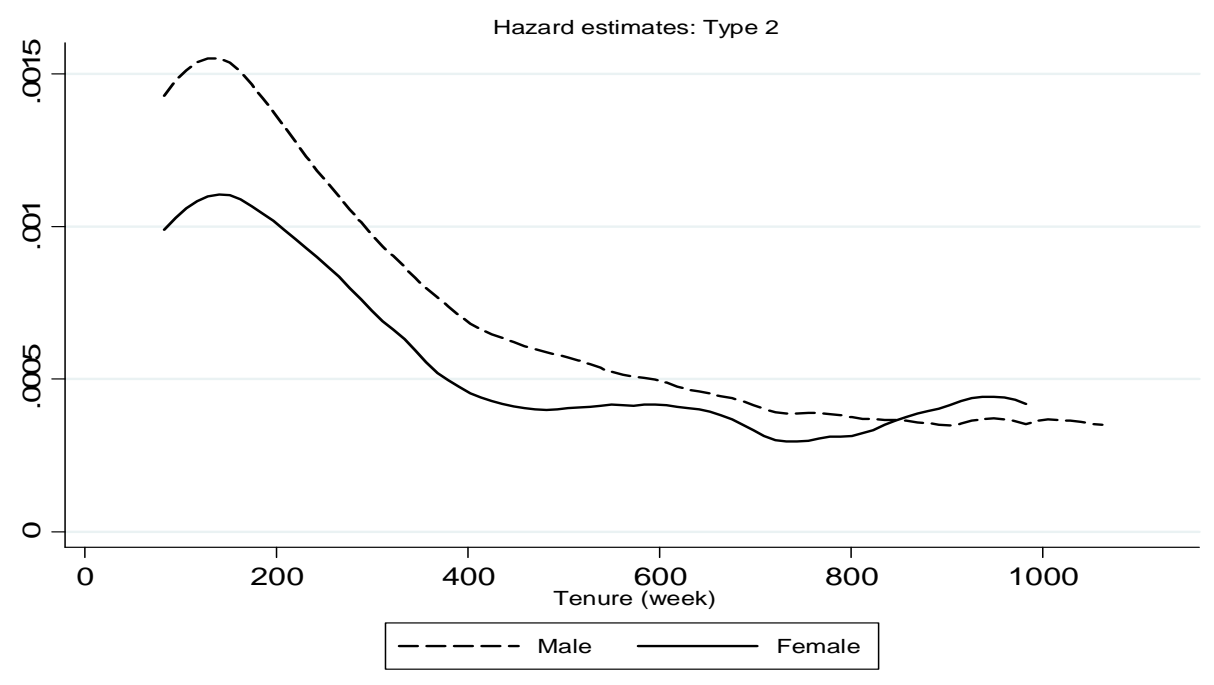

Figure 3. Turnover hazards for Type 2 turnover: quit to take another job

Finally, Table 6 presents the results for Type 3 turnover (quit for family-related reasons). Several results are remarkably different from those for other types of turnover. First, job dissatisfaction was not a key driver for Type 3 turnover for both men and women. Second, the only factor that was significant for both genders was age. Third, marital status was significant only for women. In other words, married women were much more likely than men to leave their jobs for family-related reasons. Figure 4 also confirms this result. Turnover hazards remained consistently much higher for women than men over the entire tenure, while men's turnover hazards were very small and remained virtually flat regardless of the length of tenure. 
Table 6. Cox proportional hazards regression: Type 3 (Quit for pregnancy or other family reasons)

\begin{tabular}{|c|c|c|c|c|c|c|}
\hline & \multicolumn{2}{|c|}{ All } & \multicolumn{2}{|c|}{ Male } & \multicolumn{2}{|c|}{ Female } \\
\hline & $b$ & s.e. & $b$ & s.e. & $b$ & s.e. \\
\hline Job satisfaction & -.84 & .10 & -.36 & .25 & -.04 & .11 \\
\hline Relative pay & -.03 & .14 & .29 & .28 & -.08 & .16 \\
\hline Total jobs & $.03 *$ & .01 & .06 & .03 & .03 & .02 \\
\hline Work hours & $-.01 *$ & .01 & .01 & .02 & $-.02 *$ & .01 \\
\hline Sex & $2.00^{* *}$ & .16 & & & & \\
\hline Age & $-.29 * *$ & .03 & $-.21 *$ & .09 & $-.30 * *$ & .03 \\
\hline Race & .08 & .17 & -.18 & .46 & .10 & .18 \\
\hline Married & $.59 * *$ & .17 & .25 & .45 & $.62 * *$ & .18 \\
\hline Education & -.00 & .03 & .02 & .09 & -.00 & .03 \\
\hline Log likelihood & -1178 & & -133 & & -973 & \\
\hline Log likelihood-ratio $\left(\chi^{2}\right)$ test & $235.10 * *$ & & 11.07 & & $112.86^{* *}$ & \\
\hline
\end{tabular}

Note: $\mathrm{n}=14,362$ spells. $\boldsymbol{b}$ : Coefficients. s.e.: Standard errors. **, * Significant at the $1 \%$ and $5 \%$ level, respectively.

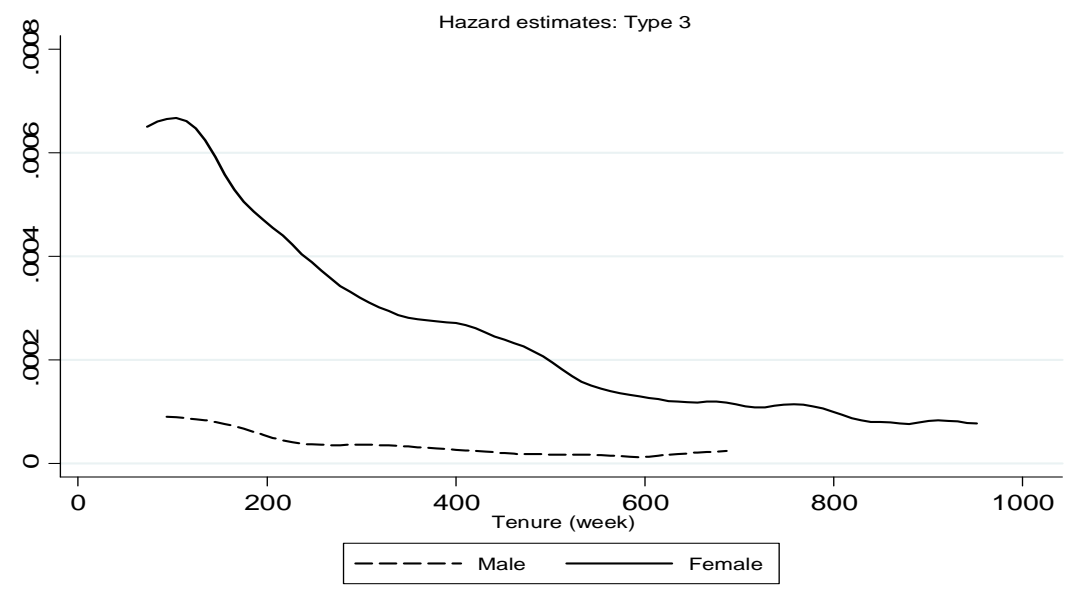

Figure 4. Turnover hazards for Type 3 turnover: quit for pregnancy or other family reasons

\section{Discussion}

With regard to the question of whether women tend to be more content with their jobs than men, this study found no evidence supporting the paradox. The results in Table 2 indicate no significant gender difference in job satisfaction when a set of control variables was included, though with no control variables, women's job satisfaction was higher. A t-test comparing the job satisfaction levels of men and women also shows that there was no significant difference between men $(\mathrm{M}=3.27, \mathrm{SD}=0.73)$ and women $(\mathrm{M}=3.29, \mathrm{SD}=0.76)$; $\mathrm{t}(14360)$, $\mathrm{p}=0.31$. Also, it should be noted that this study included stayers as well as all kinds of voluntary leavers including job-to-job, job-to-unemployment, and job-to-non-employment. Thus, women's higher job satisfaction reported in previous studies that included only stayers may be upward biased.

The second question addressed in this study is whether women have higher turnover propensities. When a turnover variable aggregating all kinds of voluntary turnover was used, the overall turnover hazard rate was indeed higher for women than men (see Table 3 and Figure 1). But, the analyses of different types of turnover based on different turnover reasons revealed considerably different turnover patterns between men and women. For instance, in Type 1 turnover, there was no significant gender difference in turnover hazards (see Table 4 and Figure 2). In Type 2 turnover, women had a higher turnover hazard rate. This result suggests that when women leave their current job for a new job, they are more likely than men to engage in job searches and leave their job after securing an alternative job (see Table 5 and Figure 3). Type 3 turnover exhibits more dramatic gender differences. Consistent with previous studies (e.g., Lee et al. 2008; Theodossiou, 2002), women consistently had higher turnover risks due to family reasons over an extended period of tenure (see Table 6 and Figure 4). In sum, given considerable gender-specific patterns in different turnover types, a general perception that women are quitters appears to be an invalid one (Light \& Ureta, 1992). 
The last question investigated is whether job satisfaction has differential effects on different types of turnover. A key finding is that job satisfaction does have differential effects on different turnover paths. Job satisfaction has very strong effects on Type 1 and Type 2 turnover. An exponentiated coefficient represents the change in the turnover hazard rate caused by a one-unit change in the corresponding covariate. For example, one unit decrease in job satisfaction increases the turnover hazard rate by $54 \%(\operatorname{Exp}(-.77)=.46)$ for male in Type 1, 53\% $(\operatorname{Exp}(-.75)=.47)$ for male in Type 2, but there is insignificant effect for male and female in Type 3. In sum, these results suggest that the role of job satisfaction in initiating turnover varies significantly in different types of turnover, which is consistent with the proposition of the unfolding model (Lee \& Mitchell, 1994).

\section{Conclusion}

This study investigated three important turnover-related topics which may have profound implications for gender inequalities in the labor market and workplace: gender differences in job satisfaction, turnover propensities, and differential effects of job satisfaction on different types of turnover. Unlike many previous studies, this study took advantage of rich information in a large national sample, and built on the framework of the unfolding model to address the above questions. In particular, this study found no evidence supportive of the first two questions, but found new evidence supporting the third question which has rarely been explored in previous research. The findings of this study imply that previous theoretical explanations and suggested remedies based on the assumption that women are more content with their jobs and more prone to turnover may not be valid anymore or may need to be revised. Women's status in the labor market has slowly yet steadily improved over the last several decades (U.S. Bureau of Labor Statistics, 2011). As Sousa-Poza and Sousa-Poza (2007) suggested, economic, sociological, and psychological factors that may have caused the observed paradox in the past may have been changing, too. More research effort needs to be devoted to these topics by utilizing a more comprehensive set of contextual factors and recent conceptual developments like the unfolding model in the turnover literature.

\section{References}

Allen, D. G., Bryant, P. C., \& Vandaman, J. M. (2010). Retaining talent: Replacing misconceptions with evidence-based strategies. Academy of Management Perspectives, 24(2), 48-64. http://dx.doi.org/10.5465/AMP.2010.51827775

Bauer, T. N., Bodner, T., Erdogan, B., Truxillo, D. M., \& Tucker, J. S. (2007). Newcomer adjustment during organizational socialization: A meta-analytic review of antecedents, outcomes, and methods. Journal of Applied Psychology, 92, 707-721. http://dx.doi.org/10.1037/0021-9010.92.3.707

Blau, F. D., \& Kahn, L. M. (1981). Race and sex differences in quits by young workers. Industrial Labor Relation Review, 34, 563-577. http://dx.doi.org/10.2307/2522478

Clark, A. E. (1997). Job satisfaction and gender: why are women so happy at work? Labour Economics, 8 , 341-372. http://dx.doi.org/10.1016/S0927-5371(97)00010-9

Clark, A. E. (2001). What really matters in a job? Hedonic measurement using quit data. Labour Economics, 8 , 223-242. http://dx.doi.org/10.1016/S0927-5371(01)00031-8

Cox, D. R., \& Oakes, D. (1984). Analysis of survival data. London: Chapman and Hall.

Crosby, F. J. (1982). Relative deprivation and working women. New York, NY: Oxford University Press.

Donohue, J. J. (1988). Determinants of job turnover of young men and women in the United States. Research in Population Economics, 6, 257-301.

Griffeth, R. W., \& Hom, P. W. (1995). The employee turnover process. Research in personnel and human resources management, 13. Greenwich, CT.: JAI Press.

Griffeth, R. W., Hom, P. W., \& Gaertner, S. (2000). A meta-analysis of antecedents and correlates of employee turnover: Update, moderator tests, and research implications for the next millennium. Journal of Management, 26, 463-488. http://dx.doi.org/10.1177/014920630002600305

Hochwater, W. A., Ferris, G. R., Canty, A. L., Frink, D. D., Ferrewe, P. L., \& Berkson, H. M. (2001). Reconsidering the job-performance-turnover relationship: The role of gender in form and magnitude. $\begin{array}{lllll}\text { Journal of Applied } & \text { Social } & \text { Psychology, } & 31, & \text { 2357-2377. }\end{array}$ http://dx.doi.org/10.1111/j.1559-1816.2001.tb00180.x

Jackofsky, E. F., \& Peters, L. H. (1983). The hypothesized effects of ability in the turnover process. Academy of Management Review, 8, 46-49. http://dx.doi.org/10.5465/AMR.1983.4287655 
Lee, T. H., Gerhart, B., Weller, I., \& Trevor, C. O. (2008). Understanding voluntary turnover: Path-specific job satisfaction effects and the importance of unsolicited job offers. Academy of Management Journal, 51, 651-671. http://dx.doi.org/10.5465/AMJ.2008.33665124

Lee, T. W., \& Mitchell, T. R. (1994). An alternative approach: The unfolding model of voluntary employee turnover. Academy of Management Review, 19, 51-89. http://dx.doi.org/10.5465/AMR.1994.9410122008

Lee, T. W., Mitchell, T. R., Wise, L., \& Fireman, S. (1996). An unfolding model of voluntary employee turnover. Academy of Management Journal, 39, 5-36. http://dx.doi.org/10.2307/256629

Light, A., \& Ureta, M., (1992). Panel estimates of male and female job turnover behavior: Can female non-quitters be identified? Journal of Labor Economics, 10(2), 156-81. http://dx.doi.org/10.1086/298283

Lynch, Lisa M. (1992). Differential effects of post-school training on early career mobility. NBER Working Paper No. 4034. Cambridge, Mass.: National Bureau of Economic Research.

Lyness, K. S., \& Judiesch, M. K. (2001). Are female managers quitters? The relationships of gender, promotions, and family leaves of absence to voluntary turnover. Journal of Applied Psychology, 86, 1167-1178. http://dx.doi.org/10.1037/0021-9010.86.6.1167

March, J. G., \& Simon, H. A. (1958). Organizations. New York, NY: John Wiley \& Sons.

Mitchell, T. R., Holtom, B. C., Lee, T. W., \& Graske, T. (2001). How to keep your best employees: Developing an effective retention policy. Academy of Management Executive, 15(4), 96-109. http://dx.doi.org/10.5465/AME.2001.5897929

Mobley, W. H., Griffeth, R. W., Hand, H. H., \& Meglino, B. M. (1979). Review and conceptual analysis of the $\begin{array}{llll}\text { employee turnover process. Psychological Bulletin, } & \text { 86, }\end{array}$ http://dx.doi.org/10.1037/0033-2909.86.3.493

Morita, J. G., Lee, T. W., \& Mowday, R. T. (1993). The regression-analog to survival analysis: A selected application to turnover research. Academy of Management Journal, 36, 1430-1464. http://dx.doi.org/10.2307/256818

Mueller, C. W., \& Wallace, J. E. (1996). Justice and the paradox of the contented female worker. Social Psychology Quarterly, 59, 338-349. http://dx.doi.org/10.2307/2787075

Phelan, J. (1994). The paradox of the contented female worker: an assessment of alternative explanations. Social Psychology Quarterly, 57, 95-107. http://dx.doi.org/10.2307/2786704

Royalty, A. B. (1998). Job-to-job and job-to-nonemployment turnover by gender and education level. Journal of Labor Economics, 16, 392-443. http://dx.doi.org/10.1086/209894

Sicherman, N. (1996). Gender differences in departure from a large firm. Industrial and Labor Relations Review, 49(3), 484-505. http://dx.doi.org/10.2307/2524199

Sloane, P. J., \& Williams, H. (2000). Job satisfaction, comparison earnings, and gender. Labour, 14, 473-502. http://dx.doi.org/10.1111/1467-9914.00142

Somers, M. J., \& Birnbaum, D. (1999). Survival versus traditional methodologies for studying employee turnover: differences, divergences and directions for future research. Journal of Organizational Behavior, 20, 273-284. http://dx.doi.org/10.1002/(SICI)1099-1379(199903)20:2<273::AID-JOB959>3.0.CO;2-X

Sousa-Poza, A., \& Sousa-Poza, A. A. (2000). Taking another look at the gender/job-satisfaction paradox. Kyklos 53, 135-152. http://dx.doi.org/10.1111/1467-6435.00114

Sousa-Poza, A., \& Sousa-Poza, A. A. (2007). The effect of job satisfaction on labor turnover by gender: An analysis for Switzerland. Journal of Socio-Economics, 36, 895-913. http://dx.doi.org/10.1016/j.socec.2007.01.022

Tett, R. P., \& Meyer, J. P. (1993). Job satisfaction, organizational commitment, turnover intention, and turnover: Path analyses based on meta-analytic findings. Personnel Psychology, 46, 259-293. http://dx.doi.org/10.1111/j.1744-6570.1993.tb00874.x

Theodossiou, I. (2002). Factors affecting the job-to-jobless turnover and gender. Laboour, 16(4), 729-746. http://dx.doi.org/10.1111/1467-9914.00214

U.S. Bureau of Labor Statistics. (2011). Women in the Labor Force: A Databook. Retrieved from http://www.bls.gov/cps/wlf-databook-2011.pdf. 